\title{
Reconstructing the Past: Reproduction of Trauma in Maxine Hong Kingston's The Woman Warrior
}

\author{
Qiong He \\ School of Literature, Languages and Linguistics, Australian National University, Canberra, Australia
}

\begin{abstract}
This article interprets The Woman Warrior as reproduction and re-composition of unspeakable traumatic memories and experience of Chinese-American women who live in an uncanny world and in diasporic condition. Drawing on trauma theory, this article studies the effects of various traumas upon the psychology of characters and examines how Kingston utilizes intertextuality as a way of demonstrating traumatic repetition and promoting healing. Intertextually revising the Chinese legend enables characters to conflate the unspeakable experience into their cognitive systems and to reconstruct a past free from trauma.
\end{abstract}

Index Terms-The Woman Warrior, intertextuality, reproduction of trauma, healing

\section{INTRODUCTION}

Immediately after published as "autobiography” in 1976, Maxine Hong Kingston's The Woman Warrior was highly appreciated by mainstream American academia, as Anthony J. Fonseca indicated that Kingston was "the most influential Asian American writer of the twentieth century" and The Woman Warrior was "the yardstick against which Asian American writers are measured"1. Also, The Woman Warrior is "the most widely taught book by a living writer in US college and universities" (Shu, 2001, p.200). Many a teaching reference book and research guide are published in the US to facilitate teaching and criticism of her ${ }^{2}$.

The enduring controversy generated by The Woman Warrior is surrounded by its "generic status". Although apparently a "memoir", for its subtitle is 'Memoirs of a Girlhood among Ghosts', the book blends together "elements of several genres, including fiction, myth, auto/biography and memoir, in a manner that is not easily categorized" (Grice, 2006, p.17). Patricia Lin Blinde (1979) first touched on the mixture of genres in Kingston's works, deeming that The Woman Warrior was characterized by juxtaposition of texts which was beneficial to reconstruct Chinese legend and the writer's personal experience (p. 51). Later, Suzanne Juhasz (1980) identified it as a typical female autobiography for it was derived from fantasy and imaginative life (p. 221), which was refuted by Joanne S. Frye (1998) who indicated that Kingston aimed at recreating female self-hood by fantastic and imaginary form rather than retreating from reality (1998, pp. 293-301).Furthermore, various criticisms have been demonstrated to discuss its narrative technique, autobiographical genre, narrative power and narrative structure.

The genre controversy among Chinese American critics is more furious, "which was first formulated along the lines of autobiographical accuracy, cultural authenticity, and ethnic representativeness" (Shu, 2001, p. 200). Likewise, the most fundamental concern of these debates, known as the "Chinese American pen wars", is the generic status of The Woman Warrior: although labeled as autobiography, it does go against the dominant definition of "autobiography as an ordered shaping of life events anchored in the so-called external world" (Wong, 1992, p.250). The Chinese American reviewer Jeffery Chan, for instance, attacks Knopf, Kingston's publisher, for "distributing an obvious fiction for fact" and regards its "autobiographical label" as a "marketing ploy"; reviewer Benjamin Tong echoes Chan's stricture by castigating it as an "obviously contrived work of "fiction passing for autobiography" (quoted in Wong, 1992, p.249). Katheryn M. Fong's criticism is more nuanced: in an open letter to Kingston, by emphasizing the significance of acknowledging fictionalization, Fong expresses the Chinese-American critics' concern about the detrimental social effect it may exert on the readers who are ignorant of Chinese and Chinese American history.

The most vociferous Chinese American critic and writer was and still is Frank Chin, who continues the accusation of Kingston, and denounces her very application of the autobiographical genre, their Orientalist disposition as well as fakery of Chinese myths. He insists that autobiography, derived from the Christian confession, is not a Chinese literary form, and it challenges the purity of Chinese-American literature. As Christians, Kingston perfectly conforms to the Christian prescriptions of Asian/Chinese stereotypical images and caters to the curiosity of white writers about exoticism. In addition, he accuses both writers of Orientalizing Chinese Americans by indicating that Chinese-American writers mission lies in revising stereotypical images and reconstructing Chinese-American history rather than promoting the transmission of these Orientalized images. Kingston's The Woman Warrior exhibits No Name Woman's adultery,

${ }^{1}$ In Contemporary World Writers: Maxine Hong Kingston, Grice also mentions that Laura Hyun Yi Kang describes The Woman Warrior as "one of a select few 'disciplinary brand names' in academia, locating Kingston along with the likes of Chaucer, Milton and Shakespeare” (2006, p.17).

${ }^{2}$ For instance, Lim, Shirley, (ed.) (1999). Approaches to Teaching Kingston's The Woman Warrior. Modern Language Association of America; Huntley, Edelma D. (2001). Maxine Hong Kingston: A Critical Companion. Westport: Greenwood Publishing Group. 
pregnancy and suicide, as well as such descriptions as "it is more profitable to raise geese than daughters"(Kingston, 1989, p. 43).Moreover, Chin complains that Kingston treacherously alters the "original" Chinese culture and myths, which is adverse to the transmission and recognition of Chinese culture.

Acknowledgedly, the concern of these critics is reasonable, for ethic writings are frequently regarded as ethnography far from literary creation, and the white writers and critics are inclined to read them as cultural documents. Nevertheless, generalizing ethic experience is definitely not an efficient way out for ethnic writers. Otherwise, Chinese American writers would be confined in the ethic position and considered as the representatives of Chinese people, instead of being honored as American writers, or even as writers, and Chinese literature would simply be regarded as the document of Chinese history and culture, forever representing China. Thus, it is indispensible for Chinese writers to break through ethnic confinement and to present multicultural writings, and Kingston is one of these writers refusing to be labeled as ethnic writer. In her letter to Shawn Wong, Kingston mentions that "why do I have to 'represent' anyone? ... None of these writers point out how and why this book is different, but merely point out its difference as a flaw" and she emphasizes that she is willing to write "tragedy", not "a guide-to-Chinatown", manifesting her determination to claim "America" (quoted in Grice, 2006, pp. 18-9).

Based on this fact, the article argues that unveiling traumatic and yet unspoken memory and depicting Chinese American women's dissociated life in diasporic condition are Kingston's writing purpose, although she is criticized for orientalizing China by demonstrating women's miserable suffering from the old Chinese society. Drawing on Cathy Caruth's idea about traumatic memory and Anna Whitehead's idea about intertextuality, this article analyzes the personal and historical trauma witnessed and experienced by the first generation Chinese-American women, and how the intertextual revision of the Chinese legend facilitates the healing of trauma. Demonstrating the past as revenant enables the writers to reconcile with and recompose the past in order to work through trauma.

\section{UnRESOlVED TRAUMA: THE FIRST GENERATION}

In the old China inundated with traditional feudal ethics and moral concepts, people were dominated by the thought that women were inferior to men. As presented in Kingston's The Woman Warrior, the narrator's father claims that "a husband may kill a wife who disobeys him. Confucius said that" (Kingston, 1989, p.193), which means, men in that period are regarded as the masters of the households, free to do as they pleased and could have a wife as well as several concubines, while women are restricted by taboos and commandments, prohibited from free choice. The expression that "Marry a rooster, follow a foster. Marry a dog, follow a dog. ... Be faithful to it. Follow it" is the best verification of this thought. Moreover, daughters in the old China were considered as worthlessness since people held that "Girls are maggots in the rice" and "It is more profitable to raise geese than daughters" (Kingston, 1989, p. 43). Under the circumstances, women suffer from traumas generated by the suppression of the patriarchal society as well as the lack of love.

Female bodies, regarded as the object of discipline, are subjected to physical punishment, mental restrictions as well as sexual abuse, which indicate that women are inescapably susceptible to trauma. In Kingston's The Woman Warrior, the trauma of the suppressed women is demonstrated by the miserable experience of No Name Aunt. After the aunt's husband makes a living abroad and fails to return home for several years, she conceives a child with another man, which results in the raid of the villagers who break into their house and smash things. What's worse, the family curses and scolds her after the villagers leave: “Aiaa, we're going to die. Death is coming. ... Look at what you've done. You've killed us. Ghost! Dead ghost! Ghost! You've never been born” (Kingston, 1989, pp. 13-14). Depressed, she drowns herself and her baby in the well after delivering him silently in a pigsty. Before her death, the aunt says, "They've hurt me too much. This is gall, and it will kill me" (Kingston, 1989, p. 14). The unexpected pain is so unbearable that she seeks for liberation by death. Actually, the deadly blow is principally the indifference of her family, their deliberating oblivion of her name and existence, since name signifies individual identity, and the forfeiture of it means the loss of one's position and existence in the history of the family.

While suffering from trauma of family, the first-generation Chinese-American women are exposed to trauma of war as well. "The Sino-Japanese war brings focus to a historical past directly experienced by the first generation"who transmits this traumatic memory to their children born in America (Lim, 2013, p. 15). The specifics of the war may "elude ready apprehension" of the second generation, whereas the horrors of it are "reinforced by the stories of immigrant parents" (Lim, 2013, p. 16). By drawing readers' attention to the war, Kingston is also involved in this reinforcement. In Kingston's The Woman Warrior, it is just after a crazy woman is stoned inappropriately by the villagers suspecting her collusion with the Japanese that Brave Orchard leaves China for America, in other words, the war prompts her to live a diasporic life.

In presenting the Sino-Japanese war, Kinston intends to demonstrate Chinese-American female immigrants' trauma generated from it by exhibiting some traumatic events witnessed by them rather than delineating the scenes of the war in details. In The Woman Warrior, Kingston demonstrates the cruelty and panic produced by the war through depicting Brave Orchard's traumatic memory about the communal stoning of a village crazy lady. During the period that refugees live in the mountains to escape the Japanese invasion, Japanese airplanes frequently cover the sky and the bombing drives people insane, every corner shrouded in death and fear. The crazy lady, regarded as inferior than a woman, naturally becomes the object for people to release their senses of dread and indignation. Witnessing this traumatic event, 
Brave Orchard departs from China for America, where instead of shaking off this memory, she is haunted by it and transmits it to her daughter. The intrusion of traumatic memory compels her to tell and reenact the event. As presented in the novel, Brave Orchard and her husband frequently play refugees, "sleeping sitting up, huddled together with their heads on each other's shoulder, their arms about each other, holding up the blanket like a little tent", while sighing, "Aiaa", demonstrating the haunting ability of traumatic memory (Kinston, 1989, p. 93).

Trauma generated from poverty, war, and cultural restrictions in the old China necessitates their migration to America with the hope of pursuing a new and independent life free from trauma. Nevertheless, in diasporic condition, they are under even more suppression and restrictions. Working hard day and night continuously is their daily routine. To survive, they have to partake in various works along with their husbands, covering works in factory, laundry, farm and so on, let alone household duties. The arduous living conditions render a psychological gap, which prompted by the sense of loss derived from their separation with their homeland allows them to become dissociated and lose themselves.

In The Woman Warrior, by depicting two entirely different life experiences before and after Brave Orchard migrates to America, Kingston reveals the vital impact of diasporic experience in American on Brave Orchard's mind. In China, Brave Orchard is a woman warrior, a bright and capable woman, and a respected doctor possessing a maid, while in America, she loses her career, and is forced to work in such places as laundry and farms on account of racial discrimination, just like other Chinese American immigrants doing the hardest jobs and yet receiving the lowest pay. She comments her own life in America:

I have worked too much. Human beings don't work like this in China. Time goes slower there. Here we have to hurry, feed the hungry children before we're too old to work. I feel like a mother cat hunting for its kittens... I can't sleep in this country because it doesn't shut down for the night. Factories, canneries, restaurants - always somebody somewhere working through the night. It never gets done all at once here. Time was different in China... It even got boring, nothing to do but fan ourselves. Here midnight comes and the floor's not swept, the ironing's not ready, the money's not made. I would still be young if we lived in China. (Kingston, 1989, pp.105-106)

The arduous life experience in American turns her from an independent Chinese modern woman into a ChineseAmerican woman losing herself and lacking cultural identity, and prompts her to realize that America, rather than an ideal state abounding with gold, is actually a country swarming with "white ghosts", which leaves her with a sense of loss caused by cultural dislocation.

The psychological trauma suffered by Brave Orchard is manifested by her physical illnesses. Encountering both racial and sexual traumas and working hard in America, she becomes mentally and physically exhausted: the tomato vines prickle her hands, washing potatoes makes her rheumatoid, and long-time working in laundry leaves her with cough and varicosity. Her body presents traumatic experience and reserves traumatic memory so that she ultimately becomes traumatized, as she indicates, "I can’t stop working. When I stop working, I hurt. My head, my back, my legs hurt. I get dizzy. I can't stop” (Kingston, 1989, p. 106). Physical pain reflects the wound in her heart, which is caused by psychological dislocation along with the suppression and discrimination from mainstream American society.

\section{TAILORING THE OLD STORIES FOR HEALING}

Healing trauma requires the transformation of traumatic memory into narrative memory, which allows the sufferer to improvise around the fixed memory of the experience, and to integrate the traumatic memory into individual's own chronology of the past. This conversion, however, mayrisk losing "both the precision and the force that characterizes traumatic recall" (Caruth, 1995, p. 153). Possessing prominent features of order and coherence, narrative consequently threatens the substantial inscrutability of the trauma, so that a narrative form free from order and coherence should be introduced to retain the traces of traumatic disruption and discontinuity. In The Woman Warrior, Kingston adopts intertextuality to tailor the old stories transmitted from her mother in order to acquire strength of working through trauma as well as to indicate the traces of trauma in writing style.

In The Woman Warrior, Kinston critically revises the legends of Mulan and Cai Yan. In the process of revision, while returning to the source texts and repeating their plot or image, Kingston also significantly departs from them. As proposed by Anne Whitehead, with its repetition and revision, intertextuality bears some relationships with trauma fiction. If the given text closely follows the source text, intertextuality can be applied to "evoke the sense that a character is following an inescapable trajectory or is caught in a repetition-compulsion", whereas if the source text is substantially modified, the novelist can "highlight trauma as a mode of departure and suggest the possibility of change or progression" (Whitehead, 2004, p. 94). In the second chapter of The Woman Warrior, "White Tigers", Kingston remains the general plot and frame of Mulan's legend, manifesting that Fa Mu Lan is destined to repeat her fate and is caught in a repetition-compulsion, and yet she also significantly revises it and reconstructs $\mathrm{Fa} \mathrm{Mu} \mathrm{Lan} \mathrm{as} \mathrm{an} \mathrm{image} \mathrm{with}$ female subjectivity, sensitivity and strength, manifesting the young narrator is seeking the ways of shaking off trauma.

Intertextuality highlights the close interrelationship between the two texts in plot or characters, thus the given story will be familiar to the reader acquiring the knowledge of the original text and the characters will inevitably repeat the previous actions and their fates is predestined from the onset in that the reader knows beforehand what will happen to them. As proposed by Whitehead, this substance of an inescapable fate "bears comparison with Freud's elaboration of the repetition-compulsion in Beyond the Pleasure Principle" (2004, p.90). These repetitions, far from being motivated by the individual, identify the possessive spirit of the fate. 
In "White Tigers", Kingston retells the story of Mulan (Fa Mu Lan in Kingston's version), which is originated from "Ballad of Mulan", a folk song of a nomadic tribe living in northern China around fifth century, depicting a girl disguised as a man goes off to war instead of his father and declines the award for her triumph so as to return home and attend to her parents. The power of this chapter is generated by the reader's foreknowledge of the plot. The reader is thus compelled to decide whether Fa Mu Lan, empowered by Kingston with individuality and female sensitivity, can ultimately cut off her fate as a traditional Chinese woman oppressed by patriarchal power. Actually, Kingston ends the story with $\mathrm{Fa} \mathrm{Mu} \mathrm{Lan's} \mathrm{return} \mathrm{to} \mathrm{her} \mathrm{family,} \mathrm{promising} \mathrm{to} \mathrm{"her} \mathrm{parents-in-law} \mathrm{that} \mathrm{she} \mathrm{will} \mathrm{stay} \mathrm{with} \mathrm{them,} \mathrm{doing}$ farmwork and housework, and giving them more sons" (Kingston, 1989, p.45). Thus, it is evident that Fa Mu Lan is destined to repeat her fate, as if caught in the "repetition-compulsion", but this time rather than happily return to domesticity, she is forced to reconcile herself to the sociopolitical system which she strives to get away from.

This repetition manifests temporal disruption of intertextuality. For Whitehead, such atemporalityechoes"the symptomatology of trauma" (2004, p.91). Caruth(1995) defines the concept of trauma as historical experience with peculiar, temporal structure, the belatedness, indicating that "not experienced as it occurs", the traumatic event is "fully evident only in connection with another place, and in another time" (p.8). It profoundly promotes intertextual fiction. As Whitehead suggested, writing in different time and space renders the modern novelist the chance to "make fully evident that which was only partially available to the author of the source text" (2004, p.92). Writing from Chinese-American perspective, Kingston reconstructs Chinese and Chinese-American women's images, unrevealing the sexual inequality concealed in "Ballad of Mulan", indicating traumatic belatedness and departure.

Intertextuality can achieve significant effects through repetition, and yet it can create new meanings by departing from the source text as well. Whitehead observes of this characteristic: "intertextuality is, like trauma, caught in a curious and undecidable wavering between departure and return" (2004, p. 90). She proposes that the intertextual novelist can "enact through a return to the source text an attempt to grasp what was not fully know or realized in the first instance, and thereby to depart from it or pass beyond it" (2004, p. 90). In "White Tiger", while indicating the repetition-compulsion catching $\mathrm{Fa} \mathrm{Mu} \mathrm{Lan,} \mathrm{Kingston} \mathrm{endeavors} \mathrm{to} \mathrm{seek} \mathrm{the} \mathrm{ways} \mathrm{for} \mathrm{her} \mathrm{character} \mathrm{to} \mathrm{"work} \mathrm{through"}$ trauma by means of departure from the original text.

Kingston revises "Ballad of Mulan" into two parts: the first half depicting Fa Mu Lan's training on the mountain by an old man and an old woman for fifteen years, and the second half presenting how she takes her father's place to join a revolution of revenge, during which she marries her husband and gives birth to a son, defeats enemies, punishes barons, establishes a "new" regime and ultimately returns home in triumph. Ostensibly, this structure manifests Kingston's attempt to be in accordance with the plot of "Ballad". Underlying the structure, however, is her endeavor to explore the ways for the female subject Maxine to cast away her trauma, namely, by constructing the image of Fa Mu Lan, a female with subjectivity, sensitivity and strength, as well as enjoying harmonious conjugal relation.

The most prominent departure from the source text is that Kingston retells the story from first-person perspective so as to render authority to $\mathrm{Fa} \mathrm{Mu} \mathrm{Lan} \mathrm{as} \mathrm{well} \mathrm{as} \mathrm{to} \mathrm{combine} \mathrm{her} \mathrm{voice} \mathrm{with} \mathrm{that} \mathrm{of} \mathrm{the} \mathrm{narrator,} \mathrm{which} \mathrm{releases} \mathrm{the}$ traumatized female bodies from the suppression of voice. Unlike the "Ballad", in which Mulan's utterances are frequently disrupted by third-person narrator speaking from a male perspective, Fa Mu Lan can author her own story in Kingston's revision, echoing feminist view of relating authorship to authority. Also, through the image of Fa Mu Lan, the narrator can express her feelings and struggle to shake off trauma. As analyzed in the previous chapter, the traumatic event of no name aunt haunts the whole family as well as the narrator herself. Terrified by the death of no name aunt, the narrator strives to shake off the fate of growing up "a wife and a slave", and is willing to "grow up a warrior woman" with power and strength to determine her own way of life (Kingston, 1989, p.20). This willing is merged with the narration of $\mathrm{Fa} \mathrm{Mu} \mathrm{Lan.} \mathrm{Through} \mathrm{first-person} \mathrm{narrative,} \mathrm{female} \mathrm{body} \mathrm{is} \mathrm{no} \mathrm{longer} \mathrm{the} \mathrm{object} \mathrm{of} \mathrm{suppression} \mathrm{and} \mathrm{silence,}$ and thus free from trauma derived from male power.

Since women's traumatic experience is generated from patricentric violence and their physical vulnerability, the narrator transforms these experiences by reconstructing the image of $\mathrm{Fa} \mathrm{Mu} \mathrm{Lan,} \mathrm{which} \mathrm{is} \mathrm{characterized} \mathrm{by} \mathrm{the}$ coexistence of womanhood and militance. When returning home from mountains after fifteen-year training, Fa Mu Lan, dressing up as a man, is welcomed as a "son", manifesting the narrator's thirst for love and cherishment from her family. Departing from the "Ballad", in which Mulan's cross-dressing is a secret remained between her and her family until her triumphal return, Fa Mu Lan's identity is shared by the villagers before she rides to the battle. Moreover, before her departure to the battlefield, her body is tattooed and carved with oath of revenge: "My father first brushed the words in ink, and they fluttered down my back row after row. Then he began cutting; to make fine lines and points he used thin blades, for the stems, large blades. My mother caught the blood and wiped the cuts with a cold towel soaked in wine" (Kingston, 1989, pp. 34-35). This corresponds to the story of Yue Fei (NgakFei in Kingston's spelling), a Chinese"national hero" who has words engraved on his back. Ultimately, this female body is transformed into an image conflating Mulan and Yue Fei. Kinston has explained: "I take the power I need from whatever myth. Thus Fa Mu Lan has the words cut into her back; in the traditional story, it is the man, NgakFei the Patriot, whose parents cut vows on his back. I mean to take his power for women" (Kingston, 1991, p.24). Both as national heroes who defend their country and resist foreign aggression, the images of Mulan and Yue Fei carry the nationalistic significance. Acquiring power from this hybrid image, the narrator seeks to remove female body from the prescribed vulnerable image, and thus protest against racism and sexism. 
Meanwhile, the revised narration displays sharmonious conjugal relation from two aspects, allowing female bodies to break off sexual trauma generated by gender inequality. First of all, the relationship of the old man and the old woman dwelling in the mountains of white tigers manifests unity of yin and yang, inseparably interconnected with and supplementary to each other, as the narrator stated, "I saw two people made of gold dancing the earth's dances", and "they turned so perfectly that together they were the axis of the earth's turning... and I understand how... one of the dancers is always a man and the other a woman" (Kinston, 1989, p. 27). Their harmonious integration indicates Kingston's speculation upon the gender relationship. Furthermore, Mulan and her husband provide another example of compatible marriage. They support and rely on each other, riding "side by side into battle" (Kinston, 1989, p.39). When giving birth to a child, she is accompanied by her husband who talks to her, rather than returns to the battlefield and leaves her alone. This is contrary to the birth scene of no name woman, who gives birth in the pigsty silently without accompany and protection after the villagers attack her house and her family abandons and curses her. This harmonious relationship releases traumatic women bodies from gender oppression, and illustrates a sort of perfect gender relation with equality, mutual assistance, mutual complementation, and integration.

Kingston does not finish the legend with Fa Mu Lan's repetition of her fate and return to her womanly life, but conflate it with the story of historical poet Cai Yan. This transformation from Fa Mu Lan to Cai Yan shows that the narrator surrenders her sword and takes up words as her weapons, signifying her rebirth from trauma. In "A Song for a Barbarian Reed Ripe", the narrator retells the legend of Cai Yan with concentration on her life after she is captured by the Huns. She reconfigures Cai Yan from a poetess into a woman who is able to fight at the battlefield, "Ts'ai Yen fought desultorily when the fighting was at a distance, and she cut down anyone in her path during the madness of close combat" (Kinston, 1989, p.208), and into a singer in the circumstance of diaspora who communicates with the barbarians through song. The reconfigured image of Cai Yan with its exiled background is more close to the traumatic environment of Chinese-American women, thus can instruct them to work through trauma. Ultimately, like Cai Yan, the narrator breaks silence, which signifies the healing of her trauma.

\section{CONCLUSION}

In The Woman Warrior, since women's traumatic experience is derived from their compelled silence, their physical vulnerability, and the unequal treatment, the narrator Maxine strives to "work through" trauma by reconfiguring the legend of Mulan so that she becomes woman warrior who seeks revenge on behalf of her family and carries their testimony on her skin, and merging the image of Mulan with the historical poet Cai Yan to express her determination to pick up words as her weapon. Kingston intertextually adopts the legends of Mulan and Cai Yan, representatively presented in "White Tigers" and "A Song for a Barbarian Reed Ripe", and inserts them into the traumatic narrative, which disrupts temporality and continuity, and introduces a psychological distance for readers to retrieve from trauma and contemplate it. This intertextuality not only manifests the haunting nature of trauma, for it repeats the general plot of the original text as if the character is caught in repetition-compulsion, but also signifies significant departure from trauma, for it tailors the legend and reconfigures a female character with subjectivity, sensitivity and strength, manifesting the narrator ultimately finds the ways of shaking off trauma.

\section{ACKNOWLEDGMENTS}

The author would like to thank Professor Feng Ya for her valuable suggestions and comments, and Sichuan University for the education and library resources it provides.

\section{REFERENCES}

[1] Blinde, Patricia Lin (1979). The Icicle in the Desert: Perspective and Form in the Works of Two Chinese-American Women Writers. MELUS6.3, 51-71.

[2] Caruth, Cathy. (ed.) (1995). Trauma: Explorations in Memory. Baltimore, MD and London: Johns Hopkins University Press.

[3] Chin, Frank. (2008). Come All Ye Asian American Writers of the Real and the Fake. In Kent A. Ono (ed.), A Companion to Asian American Studies. New York: John Wiley \& Sons, 133-156.

[4] Fong, Katheryn. (1997). To Maxine Hong Kingston: An Open Letter/Review. Bulletin for Concerned Asian Scholars 9.4, 67-69.

[5] Frye, Joanne S. (1988). The Woman Warrior: Claiming Narrative Power, Recreating Female Selfhood. In Alice Kessler-Harris and William McBrian (eds.), Faith of a (Woman) Writer. New York: Greenwood Press,293-301

[6] Grice, Helena. (2006). Contemporary World Writers: Maxine Hong Kingston. Manchester: Manchester University Press.

[7] Huntley, Edelma D. (2001).Maxine Hong Kingston: A Critical Companion. Westport: Greenwood Press.

[8] Juhasz, Suzanne. (1980). Towards a theory of form in feminist autobiography: Kate Millett's Flying and Sita; Maxine Hong Kingston's The Woman Warrior. Women's Autobiography: Essays in Criticism, 221-37.

[9] Kingston, Maxine Hong. (1989). The Woman Warrior. New York: Vintage books.

[10] Lee, A. Robert (ed.) (2008). China Fictions, English Language: Literary Essays in Diaspora, Memory, Story. Amsterdam: Rodopi.

[11] Lim, Shirley (ed.). (1999). Approaches to Teaching Kingston's The Woman Warrior. New York: Modern Language Association.

[12] Lim, Walter S. H. (2013). Narratives of Diaspora: Representations of Asia in Chinese American Literature. New York: St. Martin's Press.

[13] Shu, Yuan. (2001). Cultural Politics and Chinese-American Female Subjectivity: Rethinking Kingston's 'Woman Warrior'. 
MELUS26.2, 199-223.

[14] Whitehead, Anne. (2004). Trauma Fiction. Edinburgh: Edinburgh University Press.

[15] Wong, Sau-Ling Cynthia. (1992). Autobiography as Guided Chinatown Tour? Maxine Hong Kingston's The Woman Warrior and the Chinese American Autobiography Controversy. In James Robert Payne (ed.), Multicultural Autobiography: American Lives. Knoxville: University of Tennessee Press, 248-279.

Qiong He is currently a $\mathrm{PhD}$ candidate of English literature in Australian National University, Australia. She received her master's degree of Arts in Sichuan University, China in 2017. Her research interest includes Chinese American literature, British and Irish literature, geographies of modernism, etc. 